УДК : 327.73

\title{
ОСОБЛИВОСТІ ВИБОРЧОЇ КАМПАНІЇ У США: ТЕОРІЯ І ПРАКТИКА КАМПАНІЇ 2014 РОКУ
}

Надіслано:

03.11 .2020

Земзюліна Наталія Іванівна

доктор історичних наук, професор, Рецензовано:

Черкаський національний 10.11.2020

університет ім. Богдана Хмельницького, Прийнято: м. Черкаси, Україна 16.11 .2020

ORCID: 0000-0002-9028-2093

aklatan.zem@gmail.com

У запропонованій статті аналізуються мотиви поведінки виборців напередодні i безпосередньо під час виборів. Вказано, що розуміння закономірностей їх дій значною мірою пом'якшує несподіванку результатів виборів. Останнім часом політологи, соціологи, аналітики багато дізналися про те, як виборці насправді приймають рішення, що має остаточний вплив на їх рішення, наскільки їхні думки важливі для розуміння демократичної відповідальності і суспільного добробуту. Проте, ці дослідження спровокували більше відкритих питань, ніж відповідей. Восени 2014 року в США пройшли проміжні вибори до Конгресу. Науковці отримали черговий шанс випробувати свої версії на результатах американських виборів, відслідкувати закономірності електоральної поведінки, спрогнозувати результати. Особливо цікавою, з точки зору отриманих результатів, була поведінка виборця, відомого під назвою swing voter. У статті проведено аналіз соціального статусу виборців цієї групи, вказано можливі причини зміни іх електоральних позицій. В основу нашого дослідження покладено описовий метод і метод системного аналізу як ряду процедур збору, первинного аналізу, так і викладу даних, їх характеристик. Адміністративно ми зосередили свою увагу на Північно-Східних штатах, висновки дослідження потрібно відповідально використовувати до ситуації в інших регіонах країни. За базову методологію взято найбільш популярну в США теорію ретроспективного голосування. Ї̈̈ зміст полягає в тому, що політичні результати мають відповідати показникам компетентності та ефективності виборних посадових осіб.

Ключові слова: США; вибори; теорія ретроспективного голосування; swing voter; електоральні позиції. 
Zemzyulina Natalia, Ph.D. hab. (History), Professor, Bohdan Khmelnitsky National University of Cherkasy, Cherkasy, Ukraine

The USA Election Campaign Peculiarities: 2014 Campaign Theory and Practice

The proposed article analyzes the motives for voter behaviour before and during the election. It is stated that understanding the patterns of their actions greatly mitigates the surprise of the election results. Recently, political scientists, sociologists, and analysts have learned a great deal about how voters actually make decisions that have a final impact on their choices, how important their views are for understanding democratic responsibility and social well-being. However, these studies have provoked more open-ended questions than answers. In the fall of 2014, the United States held by-elections to Congress. Scientists have another chance to test their versions of the American election results, to monitor the electoral behaviour patterns, to predict the results. Of particular interest, in terms of results, there is the behaviour of a voter known as swing voter. The article analyzes the social status of voters in this group, indicates the possible reasons for changing their electoral positions. Our study is based on a descriptive method and a method of systematic analysis of a number of procedures for collecting, primary analysis, and presentation of data and their characteristics. Administratively, we have focused our attention on the North-Eastern states, the findings of the study should be used responsibly to the situation in other regions of the country. The basic methodology is the most popular in the United States theory of retrospective voting. Its essence is that the political results should correspond to the indicators of competence and efficiency of the elected officials.

Key words: USA; elections; theory of retrospective voting; swing voter; electoral positions.

Земзюлина Наталья Ивановна, доктор исторических наук, профессор, Черкасский национальный университет им. Богдана Хмельницкого, г. Черкассы, Украина

\section{Особенности избирательной кампании в США: теория и практика кампании 2014 года}

В предлагаемой статье анализируются мотивы поведения избирателей, накануне и непосредственно во время выборов. Указано, что понимание закономерностей их действий в значительной степени смягчает неожиданность результатов выборов. В последнее время политологи, социологи, аналитики провели много исследований о том, как избиратели на самом деле принимают решение, что оказывает окончательное влияние на их решение, насколько их мировоззрение важно для понимания демократической ответственности и общественного благосостояния. Тем не менее, эти достижения в области знаний также спровоцировали больше открытых вопросов, чем ответов. Осенью 
2014 года в США прошли промежуточные выборы в Конгресс. Политологам представился очередной шанс версифицировать свои версии результатов американских выборов. В особенности, трудности связанные с избирателем, известного под названием swing voter. В статье произведён анализ социального статуса избирателей данной группы, указаны возможные причины изменения их электоральных позиций. В основу нашего исследования положен описательный метод и метод системного анализа как ряда процедур сбора, первичного анализа и изложения данных и их характеристик. В качестве административного региона мы сосредоточили свое внимание на СевероВосточных штатах, выводы исследования нужно внимательно применять к ситуации в других регионах США. В качестве базовой методологии взяли наиболее популярную в США теорию ретроспективного голосования. В ее основе логика о том, что политические результаты являются адекватными показателями компетентности и эффективности выборных должностных лиц. Цель этой статьи проанализировать особенности избирательной кампании 2014 года в США, взяв за основу популярную теорию ретроспективного голосования и определив роль swing voter в конечных результатах голосования.

Ключевые слова: США; выборы; теория ретроспективного голосования; swing voter; электоральные позиции.

\section{Вступ}

Історично склалося, що саме орієнтація на погляди незалежних виборців приносить перемогу в умовах жорсткої конкуренції і в swingstates, тобто штатах, в яких результат голосування виборів не зрозумілий (явний) до останнього моменту, адже основні претенденти мають приблизно рівні шанси на перемогу. Ключовим елементом у механізмі політичної відповідальності є саме оцінка діяльності чинного уряду шляхом голосування. Таким способом громадяни можуть відбирати державних чиновників, усуваючи від влади тих, хто «не впорався», даючи шанс більш компетентним і чесним. Отже, демократичне правління $є$ нормативно привабливим, тому що саме вибори $\epsilon$ ефективним інструментом підвищення суспільного добробуту. В основі цих теоретичних концепцій лежить модель ретроспективного голосування, в якій громадяни розглядають інформацію про минулу діяльність уряду, щоб приймати раціональні рішення в реальному часі (Alesina, 1993).

\section{Аналіз останніх досліджень і публікацій}

Виборча тематика є предметом наукових розвідок цілої плеяди науковців різних шкіл і систем протягом останніх 50 років. Особливо дослідників цікавлять мотиви та поведінка виборців, що не мають яскравої прихильності до кандидатів. Так, Жеффрі Бреннан і Лорен Ломаско (MacRae, 1977, p. 242) 
показали, що під час голосування відповідальний та інформований виборець часто приймає аж ніяк не найкраще рішення. За даними Герберта Вейсберга, поведінку виборця можна спрогнозувати, володіючи інформацією про вісім його головних характеристик (вік, стать, фінансове становище, сімейний стан, тривалі політичні пристрасті, точка зору на злободенні політичні проблеми, оцінка нинішнього стану справ у країні, його оцінка діючої влади) (MacRae, 1977, p. 259). Американський вчений Р. Ніколсон доводить, що виборець здебільшого голосує, оцінюючи ситуацію в комплексі (Aleskerov, Ordeshuk, 1995). Сучасні джерела оцінюють безліч характеристик як електорату, так і самої політичної системи, яка постійно перебуває в динаміці (Healy, Lenz, 2014).

\section{Формулювання мети і завдань статті}

Mета статті: проаналізувати особливості виборчої кампанії 2014 року в США, взявши за основу популярну теорію ретроспективного голосування і визначивши роль swing voter у кінцевих результатах голосування.

\section{Виклад основного матеріалу дослідження}

Ретроспективне голосування можна розглядати як багаторівневий процес, який створює i розвиває зворотний зв'язок між громадянським суспільством і виконавчими органами державної влади.

Під час першої фази виборці спостерігають за подіями у світі (наприклад, епідемією), результатами економіки (наприклад, макроекономічною статистикою) i політичними діями, розпочатими виборними посадовими особами. У другій фазі виборці покладають відповідальність за ці події, результати і дії на окремих обраних посадових осіб. Потім ці оцінки спонукають людей оцінювати ефективність роботи посадових осіб, що впливає на їх рішення щодо голосування. Це третя фаза. На заключній фазі спостерігається те, як події, результати і дії перетворюються на результати виборів, створюються стимули для виборних посадових осіб, тим самим впливаючи на формування політики як до, так і після виборів. У підсумку, політичні рішення відображають події і результати, які спостерігають виборці, тобто цикл запускається заново (Barro, 1973).

Зазначена теорія враховує те, що виборці повинні бути здатні виконати життєво відповідальні завдання громадянства, такі як: дати оцінку уряду з ряду важливих питань, вміти орієнтуватися в політичних питаннях і мати стабільні ідеологічні погляди і прихильність. Кожні вибори - це не тільки оцінка уряду, але й оновлення переконань виборців, заснованих на результатах роботи влади.

При спробі ознайомитися з передвиборчими стратегіями американських політиків, може скластися хибне враження про фрагментованість їх формування. Здається, що це просто набір не пов'язаних між собою фактів, кожен з яких розвивається лише відповідно до своєї внутрішньої моделі. Тенденція зростання таких фактів збільшує фрагментацію стратегій, що, в свою чергу, збиває 
з пантелику всіх тих, хто змушений цікавитися політикою США. Однак, на наш погляд, збільшення потоку інформації про вибори не може змінити той факт, що всім політикам доводиться вирішувати приблизно однакові завдання. Це все вказує на певну схожість дій, що дозволяє нам досліджувати американські стратегії передвиборчої боротьби з метою передбачення перемоги того чи іншого кандидата.

Восени 2014 р. в США пройшли проміжні вибори до Конгресу. Таким чином, 4 листопада 2014 року відбулися зміни в політичному балансі сил в законодавчих органах. Як і раніше, виборці визначали, хто саме займе 435 місць нижньої палати Конгресу і 37 місць у Сенаті. Для демократів вибори були особливо важкі частково через те, що будь-яка партія діючого президента не часто є успішною в проміжних виборах, а ще й тому, що низький рейтинг Обами міг бути істотною перешкодою для демократичних кандидатів. У світлі вдалих збігів обставин у республіканців 3'явилася можливість отримати більше переконливих результатів на виборах (Chen, 2013).

У США кожен штат має значну автономію в прийнятті потенційно ефективних політичних рішень у сфері освіти, кримінального правосуддя i соціальних питань. Губернатори встановлюють податкові ставки як для фізичних осіб, так і для юридичних; створюють нормативні акти і програми стимулювання для конкретних галузей промисловості; контролюють значну частину фінансування освіти; вносять зміни до Кримінального кодексу і регулюють політику місцевої поліції; визначають порогові значення посібників для таких федеральних програм соціального забезпечення як Medicaid, програми медичного страхування дітей та програми додаткового харчування; встановлюють закони про мінімальну заробітну плату. Такі повноваження дають можливість мати широкий спектр політичних девідентів, які впливають на суспільство та економічні показники (Сох, 1999).

3 огляду на таку велику роль, яку уряд кожного окремого штату відіграє в прийнятті політичних рішень у США, цілком ймовірно, що ефективність економіки, системи кримінального правосуддя, шкіл, охорони здоров'я та навколишнього середовища залежить від державної політики. Отже, ці показники економічного і соціального благополуччя можуть бути хорошими індикаторами для використання в ретроспективних оцінках ефективності діяльності державних органів.

Вибори в США важливі ще й тому, що вони визначають специфіку американського політичного життя на кілька років вперед. Наявність тієї чи іншої обставини у виборчій кампанії веде до політичного шлейфу протягом всієї діяльності політика. Для того, щоб краще зрозуміти, чому американські вибори мають певні особливі риси, які впливають на діяльність «слуг народу», варто почати з розгляду деяких принципово важливих стартових умов. 
Спочатку було відомо, що у виборах 2014 р. не збиралося брати участь четверо сенаторів від демократів і двоє від республіканської партії. Зрозуміло, що різницю в два сенатора не варто пов'язувати 3 падінням рейтингу демократів. Підтвердженням цієї тези є ситуація з Палатою представників. Там брати участь у виборах відмовилися 16 демократів і 26 республіканців. Проте варто визнати, що загальна ситуація все ж більше сприяла республіканцям, ніж демократам. Тим більше, що в 2012 р. саме республіканці, отримавши 234 місця, знову сформували більшість в Палаті представників (Berry, Howell, 2007).

Як і завжди, передвиборчу кампанію в США відрізняла гра на особистісних почуттях виборців, акцент на контрастах (завтра при мені буде краще, ніж сьогодні), високий рівень оптимізму і створення штучного ажіотажу. Так само, як і раніше, рекламна компанія в ЗМІ змушувала виборців голосувати більше за імідж кандидатів, ніж за самих кандидатів. Як і раніше, чим відоміший був політик, тим вище була його популярність. Збереглася тенденція підвищення вартості виборчих перегонів: так, у 1998 р. загальна сума, витрачена на вибори, склала 1 млрд 618 млн 936 тис. 265 долара. У 2002 р. ця сума становила 2 млрд 181 млн 682 тис. 66 долара. У підсумку, в 2012 р. було витрачено 3 млрд 664 млн 141 тис. 430 долара. Середня сума витрачених переможцем коштів на кампанію склала 1 млн 567 тис. 293 долари (About Jeanne).

Як і раніше, немає єдиної класифікації американського виборця. Існує до кінця не оформлений підхід, згідно з яким усіх американських виборців можна умовно розділити на тих, хто постійно голосує за одну і ту ж партію і на незалежних виборців, тобто тих, хто не приєднувався до певної політичної партії. У свою чергу, такі громадяни діляться на дві категорії: ті, хто, як правило, схиляються до однієї з двох основних партій (їх часто називають (leaners)), i ті, хто не висловлює ніяких переваг між республіканцями і демократами (часто називають чистими незалежними (pure independents).

Труднощі, пов'язані з виборцем, відомого під назвою swing voter, досить складні й американці довгий час не знали, як вирішити їх. Спочатку термін swing voter був настільки розмитим, що його навіть не могли наповнити змістом (Beyond Red vs Blue.., 2014). Під цим терміном розуміли виборця, якого було марно переконувати, адже він постійно змінював свою думку і в день виборів голосував так, як пощастить. Такому виборцю або подобаються обидва кандидати, або йому не подобаються всі в рівній мірі. Також важливо відзначити, що swing voter не впевнений, що один з кандидатів перевершує іншого.

Більшу частину др.пол. ХХ ст. стратеги виборчих кампаній у світі не робили на такому виборцеві акценту, адже вважали низькою вірогідність 
зміни його рішення голосування. Складнісь залучення swing voter на свій бік не виправдовувалася результатами виборів.

Згодом у середовищі американських партійних стратегів утвердилася думка, що не всі виборці рівноцінні. Згідно з цією позицією, під час виборчої кампанії для успішного результату потрібно приділяти увагу тим виборцям, які, принаймні, не перейдуть на інший бік. Таким чином, кампанії, як правило, ігнорують найбільш відданих прихильників і концентрують свою пропаганду на тих незалежних, які найлегше сприймуть програму політика. I тут їхні думки розділилася. Для одних за основу для класифікації swing voter було взято дослідження американських національних виборів (ANES). ANES - це опитування населення, що проводиться в рік виборів, за яким по кожному кандидату складається шкала симпатій з 0 до 100. Swing voter - це ті, хто займає шкалу від 0 до 15 (Beyond Red vs Blue.., 2014).

Відповідно до іншого підходу, swing voter - це просто категорія незалежних виборців, яка ще називається floating voter (плаваючий виборець), тобто такий виборець, який голосує за республіканців на одних виборах, а потім за демократів - на інших (Beyond Red vs Blue.., 2014).

$€$ ряд дослідників, які згодні 3 таким визначенням: swing voter ті респонденти, які говорять соціологам, що вони не знають, як вони збираються голосувати на майбутніх виборах і не більше (Healy, Lenz, 2014).

Вважається, що для swing voter характерні такі риси, як, наприклад, менша підтримка діючих адміністрацій. Вони більш помірковані як в загальній ідеології, так і з конкретних питань. Такі виборці менше поінформовані і менше цікавиться політикою, ніж інші групи виборців. Демографічно і соціально вони неоднорідні: це жінки, молоді люди, пенсіонери, католики і вихідці з Латинської Америки.

Чи можна говорити про ту ж важливість swing voters у виборах на рівні конгресу або штату, як на рівні виборів президента? Безумовно, так. Якщо swing voters розглядати як тих, хто ще не визначився, то такі люди існують у кожному окрузі. Більше того, іноді їх відсоток на місцевих виборах вищий, ніж на президентських.

Кількість swing voter залежить від інтенсивності інформаційної кампанії. Організація і напруження президентських виборів добре забезпечують виборців даними про основних кандидатів. У президентській кампанії більшість виборців ще до осені стикаються з добре підібраними образами партійних кандидатів, які їм нав'язують по всіх можливих каналах ЗМІ.

Багато «нижчих рангом» виборчих кампаній стартують із кандидатами, які не дуже добре відомі, у результаті боротьба за тих, хто не визначився, дуже важлива. Потік агітації створює для виборців ситуацію, коли їм потрібно вибирати між кандидатом, який їм добре відомий, але до якого негативне 
ставлення і кандидата, про якого вони взагалі нічого не чули. У таких ситуаціях swing voter буде відігравати суттєву роль, тому що всі виборці будуть ділитися на 3 групи: які ніколи не чули про кандидата; які чули, але у них немає інформації, щоб прийняти рішення; обізнані виборці, які можуть дати позитивну або негативну оцінку. Виграє той кандидат, за кого проголосує swing voter, тому що, коли люди потрапляють в ситуацію невизначеності, їм доводиться використовувати поведінку інших людей в якості шаблону для власного. Чим більше людей чують позитивного про кандидата від таких же простих громадян, як і вони, тим вище його популярність (Business Conservatives, 2014).

Подібні ситуації на виборах в США не рідкість. Досить часто однопартійці не можуть домовитися і висуваються одночасно в одних округах. У підсумку, в окрузі, де більшість за одну партію, один політик упізнаваний, а інший - ні. Роль swing voter може вирости так само в тому випадку, коли обидва кандидати від різних партій мають досить високу впізнаваність, популярність і виборці не знають, кому віддати свій голос. Таким чином, можна стверджувати, що у багатьох виборчих кампаніях swingvoter - ключовий вид виборця.

\section{Висновки}

Результати здійсненого дослідження дозволяють зробити висновок про те, що ряд основних чинників, що впливають на вибір виборця, не зазнав радикальних змін: це вік, досвід, ідеологія, стать, раса і релігія, які накладаються на ситуативні виборчі обставини.

Голосування - це завжди спроба виборців визначити у спектрі політичних партій найкращу наявну команду політичних лідерів на основі того, що минулі результати можуть генерувати раціональні очікування щодо майбутніх результатів.

Ретроспективне голосування - це концепція в американській політичній науці, суть якої зводиться до того, що суспільство може оцінювати минулу політичну діяльність уряду. Виборці розглядають діяльність уряду за такими критеріями як ефективність економіки, системи кримінального правосуддя, соціальної стабільності, екологічні та медичні результати за терміни, встановлені виборами (2-4 роки), а потім через голосування на виборах громадяни формулюють прихильність більш успішному уряду (Alt, 2011).

Теоретики припускають, що існують реальні, постійні відмінності в компетентності між конкуруючими політичними елітами. Розрив у результатах діяльності партій в органах державної влади носить причинний, а не випадковий характер (Gomez, Wilson, 2001).

Різниця обумовлена різною ідеологічною основою політики партій, що проводиться на державному рівні. Партії по-різному формують бюджет, що призводить до радикальних змін у сферах освіти, медицини та національної безпеки. Саме це дозволяє поширити минулі оцінки ефективності партій 
на їх поведінку в майбутньому, незалежно від того, чи були вони в уряді або в опозиції.

Обмеженість методів досліджень та надшвидкий розвиток технологій психологічного, віртуального впливу на виборця під час виборів полягає в тому, що науковці не можуть гарантувати 100 \% вірогідність конкретних результатів при конкретних умовах або однозначно передбачити стан американського чи якогось іншого суспільства в майбутньому. Ми свідомо не акцентували увагу на ролі ЗМІ в проведенні виборчої кампанії. Інформаційний аспект кожної знакової виборчої кампанії $є$ предметом комплексних і системних наукових досліджень, оскільки засоби масової інформації у кожній із цих кампаній відіграють певну роль і впливають на імідж та рейтинг кандидатів. Отже, питання формування електорату, його світоглядні уподобання і прогнозування виборчих кампаній залишається відкритим.

\section{References:}

1. About Jeanne. Jeanne Shaheen U.S. Senator for New Hapshire, [online]. Available at: http://www.shaheen.senate.gov/about/biography/.

2. Alesina, A., Londregan, J., Rosenthal, H. (1993). 'A model of the political economy of the United States'. American Political Science Review , Vol. 87, issue 1, pp. 12-33 DOI:10.2307/2938953.

3. Aleskerov, F., Ordeshuk, P. (1995). Vyiboryi. Golosovanie [Elections. Vote]. Moscow: Nauka.

4. Alt, J., Bueno de Mesquita, E., Rose, S. (2011). 'Disentangling accountability and competence in elections: evidence from US term'. The Journal of Politics, Vol. 73, no. 1, pp. 171-186.

5. Barro, R. J. (1973). 'The control of politicians: an economic model'. Public choice, Vol. 14, no. 1, pp. 19-42.

6. Berry, C. R., Howell, W. G. (2007). 'Accountability and local elections: Rethinking retrospective voting'.The Journal of Politics, Vol. 69, no. 3, pp. 844-858.

7. Beyond Red vs. Blue: the political typology. (2014). Pew Research Centre U.S. Politics and Policy, [online]. Available at: http://www.peoplepress.org/2014/06/26/the-political-typology-beyond-red-vs-blue/.

8. Business Conservatives. (2014). Pew Research Centre U.S. Politics and Policy, [online]. Available at: http://www.people-press.org/2014/06/26/typologycomparison/types/business-conservatives/.

9. Chen, J. (2013). 'Voter partisanship and the effect of distributive spending onpolitical participation'. American Journal of Political Science, Vol.57, no. 1, pp. 200-217.

10. Cox, G. W. (1999). 'The empirical content of rational choice theory: A reply to Green and Shapiro'. Journal of Theoretical Politics, Vol. 11, no. 2, pp. 147-169. 
11. Gomez, B. T., Wilson, J. M. (2001). 'Political sophistication and economic voting in the American electorate: A theory of heterogeneous attribution'. American Journal of Political Science, Vol. 45, no. 4, pp. 899-914. DOI: 10.2307/2669331.

12. Healy, A., Lenz, G. S. (2014). 'Substituting the End for the Whole: Why Voters Respond Primarily to the Election-Year Economy'. American Journal of Political Science, Vol. 58, no. 1, pp. 31-47. DOI:10.1111/AJPS.12053.

13. MacRae, D.C. (1977). 'Substituting the end for the whole: Why voters respond primarily to the election year economy'. American Journal of Political Science, Vol. 58, no. 1, pp. 31-47.

(C)Земзюліна H. I., 2020 